\title{
Electrochemical Investigation of DNA Adsorbed on Conducting Polymer Modified Electrode
}

\author{
Zhuang LI, Hongda WANG, Shaojun DoNG, and Erkang WANG
}

Laboratory of Electroanalytical Chemistry, Changchun Institute of Applied Chemistry, Chinese Academy of Sciences, Changchun, Jilin 130022, P.R.China.

\begin{abstract}
Detection of DNA is a very important task for molecular biology and biomedical field. We have investigated electrochemical behavior of double-stranded DNA and single-stranded DNA adsorbed on conducting polymer modified electrode in presence of cobalt complex. The possibility of using such electrode as gene detector is discussed.
\end{abstract}

Key words DNA, sensor, polypyrrole, immobilization.

In the past years, gene detection based on DNA hybridization ${ }^{1}$ for use in clinical analysis ${ }^{2-4}$, environmental monitoring ${ }^{5}$, and so on, has become a research area of great interest. However, the traditional methods, radioisotope technologies, were not applicable to a routine environment owing to the radioisotopic contaminants.Various novel techniques, such as non-radioactive labeling ${ }^{6,7}$, the polymerase chain reaction (PCR) ${ }^{8}$ have been developed to replace traditional methods. However, the cost of the techniques are too high to be applied widely.

Recently, DNA sensors ${ }^{9-12}$, novel techniques for detecting DNA specific sequence, are developed quickly due to its great promise for rapid and lowcost DNA detection. Generally, the first step of the techniques is the immobilization of a single-stranded DNA (ssDNA) probe onto the electrochemical, optical ${ }^{13}$ or acoustic transducers ${ }^{14}$. Then, the ssDNA immobilized ssDNA recognizes the complementary in a sample solution and hybridization happens at the same time. Finally, the signal of hybridization is converted into an electrical signal by special transducer.

In all DNA sensors, the voltammetric DNA sensor (VDS) is attractive ${ }^{\text {is }}$ because the sensitivity of VDS is high owing to the straight conversion of electrical signal, and the DNA sensor can be performed by simple cyclic voltammetry or linear sweep voltammetry. The important step of studying the VDS is the immobilization of DNA probe. Hashimoto ${ }^{16}$ and Mikkelsen ${ }^{17}$ immobilized the DNA probe by adding a mercaptohexyl group to 5'phosphate end or adding polydeoxyguanosine to the 3 '-end and obtained high detecting sensitivity. However, the methods require the procedures of synthesis and purification which raise the cost and complexity of DNA detection. Wang's method of immobilizing DNA ${ }^{18}$ is simple and rapid by 
adsorbing DNA onto carbon paste electrode surface at positive potential, but the DNA sensor is difficult to be reused under the denatured conditions of heating and $8 \mathrm{~mol} / \mathrm{L}$ urea.

In this paper, we report a new, rapid, low-cost method of immobilizing DNA using polypyrrole (PPy) film as a medium to adsorb DNA molecules. The PPy film adsorbs DNA stably and is synthesized by simple electropolymerization.

\section{Experimental}

\section{Materials}

Calf thymus DNA (CT DNA) was purchased from Sino-American Biotechnology Company and was used without further purification. Denatured CT DNA was produced by heating native CT DNA in a water bath at $100^{\circ} \mathrm{C}$ for about $15 \mathrm{~min}$ following by rapid cooling in an ice bath. Pyrrole (98\%, Aldrich) was purified prior to use by distilling pyrrole under $\mathrm{N}_{2}$. Tris(1,10-phenanthroline) cobalt(III) perchlorate $\left(\mathrm{Co}(\mathrm{phen})_{3}\left(\mathrm{ClO}_{4}\right)_{3}\right)$ was prepared from cobalt(II) chloride, 1,10-phenanthroline, perchloric and bromine according to published procedures ${ }^{19}$.

Briefly, the mixture of $\mathrm{CoCl}_{2} \cdot 6 \mathrm{H}_{2} \mathrm{O}(2.0 \mathrm{~g})$ in water $(40 \mathrm{ml})$ and 1,10-phenanthroline hydrate $(5.0 \mathrm{~g})$ in methanol $(5 \mathrm{ml})$ was set to reflux for 30 min with $\mathrm{Br}_{2}$ water $(20 \mathrm{ml})$. Then $\mathrm{HClO}_{4}(70 \%, 20 \mathrm{ml})$ was added to the hot solution. The suspension was cooled (ice) and the product was recrystallised twice from hot water. Analytical reagent grade cobalt(II) chloride, bromide, perchloric and hydrochloric acids, citrate, sodium chloride, $\mathrm{NaH}_{2} \mathrm{PO}_{4}, \mathrm{Na}_{2} \mathrm{HPO}_{4}$ and urea were used as received. The water used for all solutions was purified using a four-filter Milli-Q System and had a final resistivity of $18.2 \mathrm{M} \Omega / \mathrm{cm}$.

\section{Apparatus}

Cyclic voltammetry was performed with a $\mathrm{CHI} 660$ Electrochemical Workstation (USA), in three electrodes cell using glassy carbon (4 mm inner diameter) as working electrode, saturated calomel electrode (SCE) as reference electrode and a platinum wire coil $(0.8 \mathrm{~mm}$ diameter $)$ as auxiliary electrode. The glassy carbon (GC) working electrode was mechanically polished successively with $\alpha$ $\mathrm{Al}_{2} \mathrm{O}_{3}$ powder of $1.0,0.3$ and $0.05 \mu \mathrm{m}$ and washed with double-distilled water in an ultrasonic water bath prior to use.

\section{Preparation of $P P y / G C$ electrode}

Polypyrrole film modified electrode was prepared by cyclic voltammetry $(\mathrm{CV})(-0.2 \sim 0.7 \mathrm{~V})$ electrooxidizing an unstirred aqueous solution of 0.1 $\mathrm{mol} / \mathrm{L}$ pyrrole containing $0.1 \mathrm{~mol} / \mathrm{L} \mathrm{NaCl}$ as electrolyte in a $0.02 \mathrm{~mol} / \mathrm{L}$ phosphate buffer ( $\mathrm{pH} \mathrm{7.0)}$. Thickness of PPy film was controlled by the charge consumed during electrolysis.

\section{Immobilization of DNA}

Adding $1 \mu$ l hydrochloric acid $(1 \mathrm{~mol} / \mathrm{L})$ into $1 \mathrm{ml}$ DNA solution containing CT DNA $(0.5 \sim 1.0 \mathrm{mg} / \mathrm{mL})$ and $\mathrm{NaCl}(0.1 \mathrm{~mol} / \mathrm{L})$ to keep the solution acidic; then, the PPy/GC electrode was immersed into the DNA solution for several minutes, and gentlely washing the DNA/PPy/GC electrode for $30 \mathrm{~s}$ with a $0.02 \mathrm{~mol} / \mathrm{L} \mathrm{NaCl}, 0.02 \mathrm{~mol} / \mathrm{L}$ phosphate buffer $(\mathrm{pH}$ 7.0) to wash off non-adsorbed DNA.

The surface was rinsed carefully with a 0.02 $\mathrm{mol} / \mathrm{L} \mathrm{NaCl}$ and $0.02 \mathrm{~mol} / \mathrm{L}$ phosphate buffer $(\mathrm{pH}$ 7.0) for a short time (5 s) prior to each medium exchange. Successive measurements were carried out by renewing the surface and repeating the above procedure (using a new solution). All data were obtained at room temperature $\left(17 \pm 2^{\circ} \mathrm{C}\right)$.

\section{Results and Discussion}

The fact that the bare smoothing GC electrode surface does not adsorb DNA in a solution had been demonstrated by Mikkelsen ${ }^{17}$ and our experiments. To detect DNA at GC electrode, we modified a layer of PPy film on GC as a medium to adsorb DNA molecules. PPy is a kind of conducting polymer material and its characteristics has been well studied 20-24 PPy on electrode surface forms threedimensional porous structure with high surface-tovolume ratio ${ }^{25-26}$; its average pore size has been estimated as $5.0-10.0 \mathrm{~nm}^{26}$. The pores benefit DNA hybridization owing to reducing the contact 

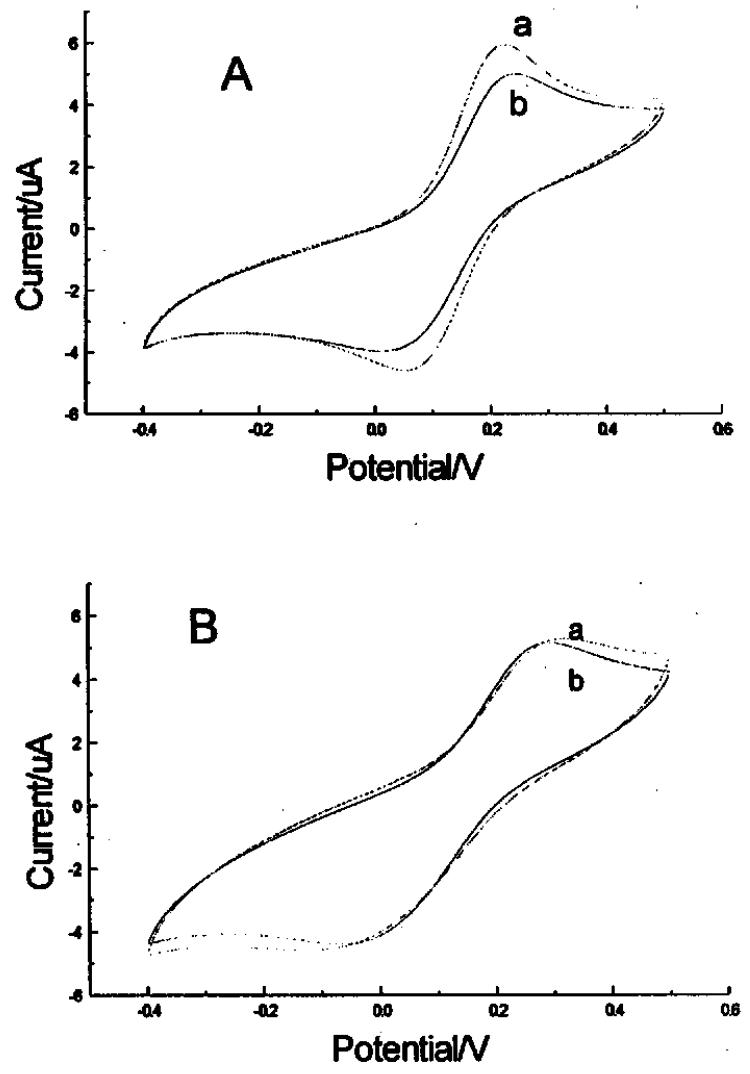

Fig. 1. Cyclic voltammograms of $0.3 \mathrm{mmol} / \mathrm{L} \mathrm{Co}(\text { phen })_{3}{ }^{3+}$ (a) with and (b) without DNA adsorbed on PPy/GC electrode; conditions: $0.02 \mathrm{~mol} / \mathrm{L}$ phosphate buffer $(\mathrm{pH}$ 7.0) with $0.02 \mathrm{~mol} / \mathrm{L} \mathrm{NaCl}$, scan rate $100 \mathrm{mV} / \mathrm{s}$. The PPy modified electrode was prepared by $\mathrm{CV}$ electrooxidizing $0.1 \mathrm{~mol} / \mathrm{L}$ pyrrole solution containing $0.1 \mathrm{~mol} / \mathrm{L} \mathrm{NaCl}$ and $0.02 \mathrm{~mol} / \mathrm{L}$ phosphate buffer (pH 7.0) (potential scan range: $-0.2 \sim 0.7$, scan rate: $100 \mathrm{mV} / \mathrm{s}$, potential cycle number: 20); then putting the electrode in a $1 \mathrm{ml} 0.75$ $\mathrm{mg} / \mathrm{ml}$ (A) dsDNA or (B) ssDNA solution containing $1 \mu \mathrm{l}$ $\mathrm{HCl}(1 \mathrm{~mol} / \mathrm{L})$ and $0.1 \mathrm{~mol} / \mathrm{L} \mathrm{NaCl}$ for $5 \mathrm{~min}$.

points between PPy and DNA adsorbed on PPy film. Further, there are positive charges on the surface of PPy film at the potential of over $-0.3 \mathrm{~V}$ (vs. SCE) ${ }^{27}$, thus DNA with a great number of negative charges on molecule surface can be stably adsorbed on the $\mathrm{PPy}^{+}$film.

To detect the electrical signal of DNA molecule which is electroinactive at the range of $-0.9 \sim 1.0 \mathrm{~V}$ (vs. SCE) ${ }^{15}$, we selected $\mathrm{Co}(\text { phen })_{3}{ }^{3+}$ as an

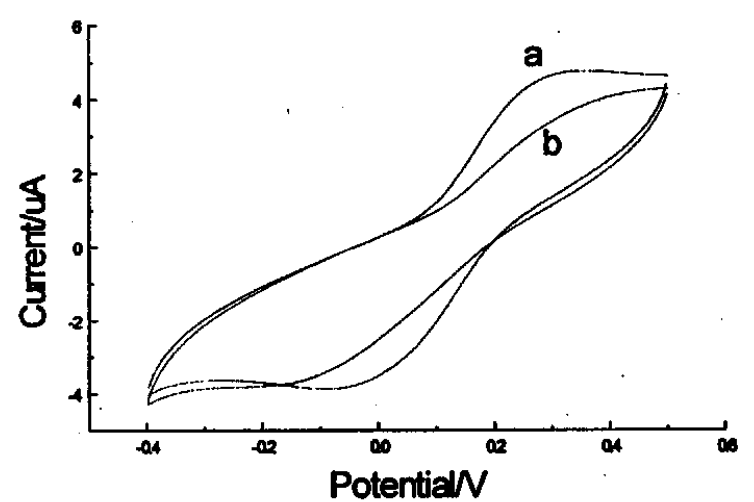

Fig. 2. Cyclic voltammograms of $0.3 \mathrm{mmol} / \mathrm{L} \mathrm{Co}(\text { phen })_{3}{ }^{3+}$ (a) with and (b) without DNA adsorbed on PPy/GC electrode; film thickness: $\mathbf{7 5}$ cycles; other conditions as in Fig 1.

electroactive indicator. $\mathrm{Co}(\text { phen })_{3}{ }^{3+}$ is reversibly electroactive (le) with the peak potentials of $E_{p c}=$ $0.095 \mathrm{~V}$ and $\mathrm{E}_{\mathrm{pa}}=0.160 \mathrm{~V}$ (vs. SCE) at glassy carbon-working electrode [28]. The complex as an indicator intercalates between the stacked base pairs of native dsDNA.

Figure 1A shows the difference between adsorbed and non-adsorbed dsDNA on the GC/PPy electrode surface. The anodic peak currents are 5.99 and 5.01 $\mu \mathrm{A}$ respectively, the difference of the peak currents $\left(\Delta i_{p}\right)$ is $0.98 \mu \mathrm{A}$; further, after more than 20 cycles, the peak currents do not change (not shown). These data demonstrate that DNA molecule had been adsorbed on PPy film surface stably by electrostatic interaction and $\mathrm{Co}(\text { phen })_{3}{ }^{3+}$ had been concentrated around the DNA molecule by intercalation and static electricity. Figure 1B shows the difference between adsorbed and non-adsorbed ssDNA on PPy film. The difference of the peak currents $\left(\Delta \mathrm{i}_{\mathrm{p}}\right)$ is $0.10 \mu \mathrm{A}$, which is much lower than dsDNA. The result suggests that the adsorption of $\mathrm{Co}$ (phen $)_{3}{ }^{3+}$ onto ssDNA molecule by static electricity was weak compared to intercalation. Overall, the difference between results of ssDNA and dsDNA indicates that the GC electrode modified by PPy film can be used as a substrate electrode to distinguish between ssDNA and dsDNA. 
Table 1. Effect of PPy film thickness on the peak current.

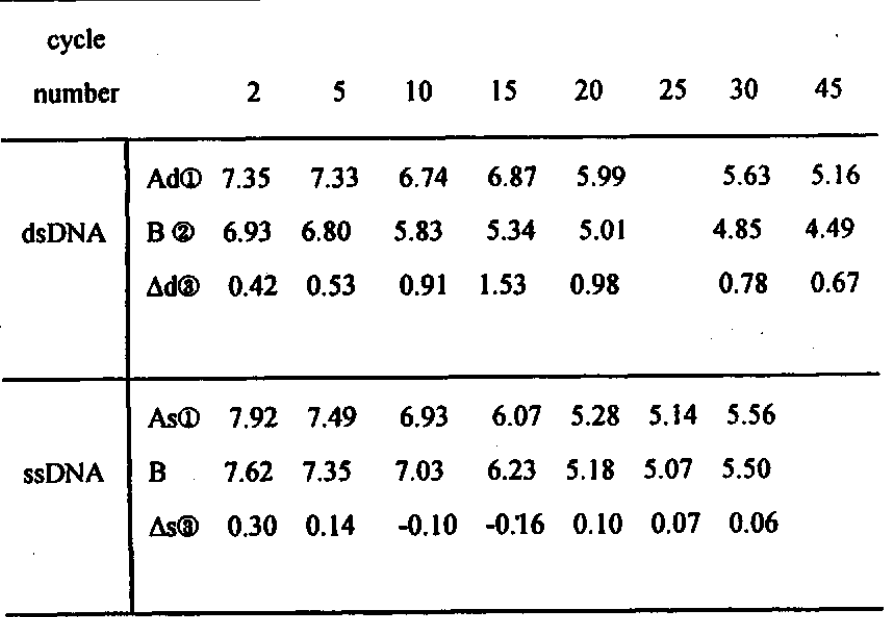

(1) Ad; As: the peak current of dsDNA and ssDNA adsorbed on PPy electrode, respectively.

(2) B: the peak current of PPy electrode without DNA adsorbed.

(3) $\Delta \mathrm{d} ; \Delta s$ : the peak current difference between Ad and B, or As and $B$.

Conditions as in figure 1 .

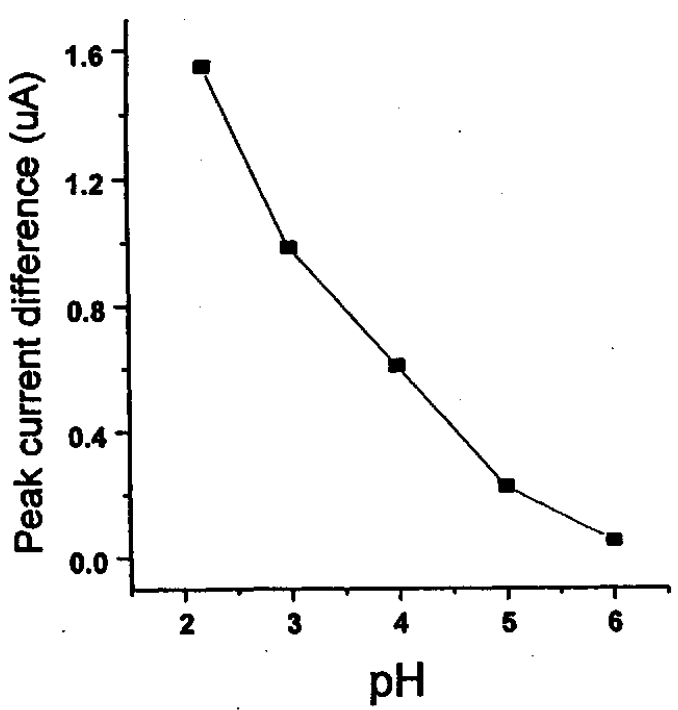

.Fig. 3. The difference of anodic peak current for 0.3 $\mathrm{mmol} / \mathrm{L} \mathrm{Co}$ (phen) ${ }_{3}{ }^{3+}$ between DNA and no DNA adsorbed on PPy/GC electrode surface as a function of DNA solution $\mathrm{pH}$; other conditions as in Fig 1.

\section{Influence of the thickness of PPy film}

The number of potential cycles during electropolymerization of pyrrole can be used to estimate the thickness of the polypyrrole on glassy carbon electrode owing to the more charge consumed, the thicker PPy forms on the GC electrode. Figure 2 shows the $\mathrm{CV}$ result of 0.3 $\mathrm{mmol} / \mathrm{L} \mathrm{Co(phen)})_{3}{ }^{3+}$ on a thicker PPy modified electrode (PPy/GC electrode was prepared by electropolymerization of pyrrole with 75 cycles). In the curve, no apparent peak is found and $\Delta E\left(E_{p a}-E_{p c}\right)$ is wider than that in figure $1 \mathrm{~A}$. The result suggests that thicker PPy film is not suitable to detect DNA. Table 1 shows the influence of thickness of PPy film on $\Delta i_{p}$ (the difference between the peak currents of DNA and no DNA adsorbed on the PPy film). For dsDNA, firstly, the $\Delta i_{p}$ increases with increasing the thickness of PPy film and reaches the maximum at the film thickness of 15 cycles; Then the difference value decreases with continuing to increase the number of cycles. This fact indicates that the increasing of the thickness of PPy film in some content strengthens the adsorption of DNA molecule due to the increasing of positive charge on PPy film surface; however, as the thickness of PPy film continues to increase, the transfer of charge becomes slower, as a result, the $\Delta i_{p}$ becomes smaller and the sensitivity of detecting DNA decreases.

\section{The influence of $p H$}

The $\mathrm{pH}$ of the solution containing DNA drastically

influences the adsorption of DNA molecule onto PPy film surface. Figure 3 shows that the $\Delta i_{p}$ increases quickly as $\mathrm{pH}$ decreases. The result suggests that the quantity of the surface charge of PPy film has a functional relation with $\mathrm{pH}$. The relation may be explained by the following reaction 29:

$$
-\mathrm{Py}^{+} \mathrm{H}-+\mathrm{H}^{+}=-\mathrm{Py}^{+} \mathrm{HH}^{+}-
$$

The positive charge on PPy film surface will increase as plenty of doping hydrogen ion in an acidic solution, as a result, the PPy film adsorbs DNA molecule much more and more compacted. However, for the detection of DNA molecule, the $\mathrm{pH}$ value cannot be lower than 4.0 owing to the depurination. On the basis of the above discussion, the pH 3.0 4.0 may be the better $\mathrm{pH}$ range of DNA adsorption in a solution for a short time. 


\section{The influence of DNA adsorbing time}

Figure 4 shows the time curve of DNA adsorption. In the first one minute, the $\Delta i_{p}$ increases rapidly; after one minute, the $\Delta \mathrm{i}_{\mathrm{p}}$ keeps stable. The result suggests that the adsorption of DNA molecules onto PPy film surface is controlled by dynamics and the DNA adsorption reaches saturation in one minute. Once the

surface is saturated by DNA, the DNA molecules would repulse the other non-adsorbed DNA molecules by electrostatic interaction, as a result, the other molecules can not be adsorbed onto PPy film surface any more.

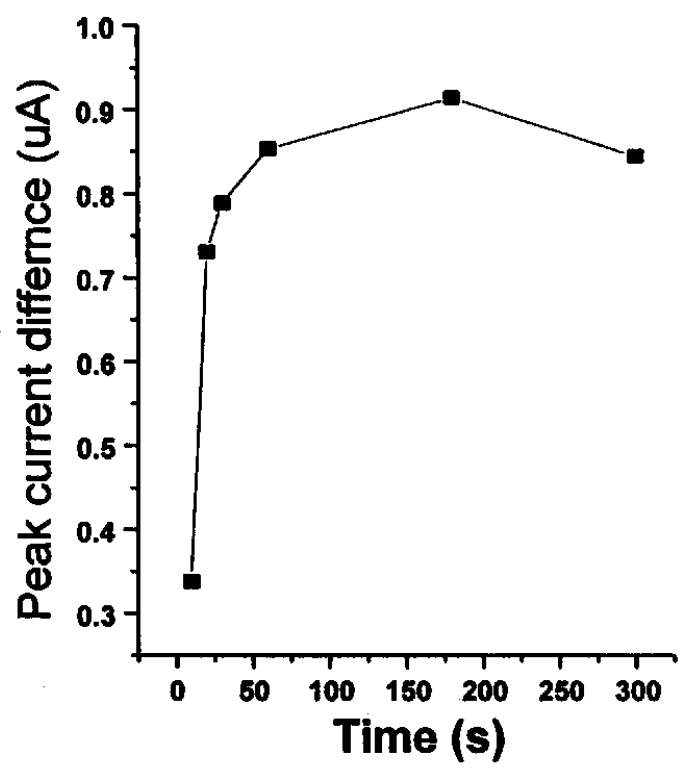

Fig. 4 . The difference of anodic peak current for 0.3 mmol/L Co(phen $)_{3}{ }^{3+}$ between dsDNA and no DNA adsorbed on PPy/GC electrode surface as a function of adsorption time. Conditions: potential cycle number: 20 ; $0.02 \mathrm{~mol} / \mathrm{L}$ phosphate buffer $(\mathrm{pH} 7.0)$, containing 0.02 $\mathrm{mol} / \mathrm{L} \mathrm{NaCl}$; scan rate: $100 \mathrm{mV} / \mathrm{s}$. The $\mathrm{PPy} / \mathrm{GC}$ electrode was immersed in a $1 \mathrm{ml}$ DNA solution containing 0.75 $\mathrm{mg} / \mathrm{ml} \mathrm{dsDNA}, 0.1 \mathrm{~mol} / \mathrm{L} \mathrm{NaCl}$ and $1 \mu \mathrm{l} \quad \mathrm{HCl}(1 \mathrm{~mol} / \mathrm{L})$ for $5 \mathrm{~min}$.

\section{The influence of urea and heating}

The drastically denatured conditions, urea and heating, destroy the PPy/DNA/GC electrode in different extents. The PPy film was destructed partly by putting PPy/GC electrode into boiling water bath for $5 \mathrm{~min}$. The result demonstrates that heating denaturation of dsDNA molecules to reuse the modified electrode would not be successful. We also studied the influence of $8 \mathrm{~mol} / \mathrm{L}$ urea and found that the results varied with temperature. When putting $\mathrm{DNA} / \mathrm{PPy} / \mathrm{GC}$ into $8 \mathrm{~mol} / \mathrm{L}$ urea solution $\left(50^{\circ} \mathrm{C}\right)$ for $10 \mathrm{~min}$, the $\Delta \mathrm{i}_{\mathrm{p}}$ did not change. The result suggests that the DNA/PPy/GC was not destructed; however, when heating the modified electrode at $70^{\circ} \mathrm{C}$ under the same other conditions, the $\Delta \mathrm{i}_{\mathrm{p}}$ changed apparently, which indicates the DNA/PPy/GC had been destructed. All the results demonstrate that DNA/PPy film can resist the treatment of $8 \mathrm{~mol} / \mathrm{L}$ urea at low temperature. Thus we may utilize the conditions to denature the short-chain dsDNA on PPy modified electrode in order to reuse the DNA sensor.

\section{Conclusion}

A new substrate, PPy modified electrode, for immobilizing DNA has been studied. The PPy modified electrode can be made conveniently and low-cost. The positive charges on PPy film surface in an acidic solution adsorb DNA stably and the PPy film resist mild denatured condition to a certain extent which provides the possibility of reusing the DNA sensor based on PPy film. These results imply that the newly developed method of immobilizing DNA is quick and convenient for the investigation of DNA sensors.

\section{References}

1. U. Landegren, R. Kaiser, C. Caskey, L. Hood, Science, 242, 229 (1988).

2. K. Millan, A. Saraullo, S. Mikkelsen, Anal. Chem., 66, 2943 (1994).

3. A. M. O. Brett, S. H. P. Serrano, T. A. Macedo, Electroanalysis, 8, 992 (1996).

4. J. Wang, X. Cai, G. Rivas, H. Shiraishi, Anal. Chem., 68, 2629 (1996).

5. J. Wang, G. Rivas, D. Luo, X. Cai, Anal. Chem., 68, 4365 (1996). 
6. G. Gentilomi, E. Ferri, S. Girotti, Anal. Chim. Acta., 255, 387 (1991).

7. Y. Kan, F. Chehab, Proc. Natl. Acad. Sci. U. S. A., 86, 9178 (1989).

8. J. Sevall, H. Prince, G. Garratty, Clin. Chem., 39, 433 (1993).

9. K. Hashimoto, K. Ito, Y. Ishimori, Anal. Chim. Acta., 286, 219 (1994).

10. K. Ito, K. Hashimoto, Y. Ishimori, Anal. Chim. Acta., 327, 29 (1996).

11. N. Kawazoe, Y. Ito, Y. Imanishi, Anal. Chem., 68, 4309 (1996).

12. J. Wang, E. Palecek, P. Nielsen, X. Cai, J. Am. Chem. Soc., 118, 7667 (1996).

13. P. Piunno, U. Krull, R. Hudson, Anal. Chim. Acta., 288, 205 (1994).

14. H. Su, K. Kallury, M. Thompson, A. Roach, Anal. Chem., 66, 769 (1994).

15. S. Mikkelsen, Electroanalysis, 8, 15 (1996).

16. K. Hashimoto, K. Ito, Y. Ishimori, Anal. Chem., 66, 3830 (1994).

17. K. Millan, A. Spurmanis, S. Mikkelsen, Electroanalysis, 4, 929 (1992).

18. J. Wang, X. Cai, G. Rivas, H. Shiraishi, Anal.
Chim. Acta., 326, 141 (1996).

19. L. Dollimore, R. Gillard, J. Chem. Soc., Dalton Trans., 933 (1973).

20. A. Diaz, K. Kanazawa, G. Gardini, J. Chem. Soc., Chem. Commun., 635 (1979).

21. S. J. Dong, J. Ding, Synth. Met., 20, 119 (1987).

22. S. J. Dong, J. Ding, J. Chem. Soc., Faraday Trans. I., 85, 1599 (1989).

23. E. K. Wang, Y. Liu, Z. Samec, Electroanalysis, 2, 623 (1990).

24. E. K. Wang, Y. Liu, S. J. Dong, J. Ding, $J$. Chem. Soc., Faraday Trans., 86, 2243 (1990).

25. S.W.Feldberg, J.Am.Chem.Soc.,106, 4671 (1984).

26. M. Umana, J. Waller, Anal. Chem., 58, 2979 (1986).

27. H. Eisazadeh, G. Spinks, G. Wallace, Materials. Forum. 16, 341 (1992).

28. M. T. Carter, A. J. Bard, J. Am. Chem. Soc., 109, 7528 (1987).

29. Q. B. Pei, R. Y.Qian, Synth. Met., 45, 35 (1991). 